\title{
ALEXANDRIA
}

Revista de Educação em Ciência e Tecnologia

\section{A Rede Temática e o Ciclo Temático na Busca pela Cultura de Participação na Educação CTS ${ }^{1}$}

\section{The Thematic Network and the Thematic Cycle in the Search for the Culture of Participation in Science-Technology-Society Education}

\author{
Júlio César Lemos Milli ${ }^{a}$; Eliane dos Santos Almeida ${ }^{\mathrm{a}}$; Simoni Tormöhlen Gehlen ${ }^{\mathrm{a}}$ \\ a Departamento de Ciências Exatas e Tecnológicas, Universidade Estadual de Santa Cruz, Ilhéus, Brasil - \\ juliocesarmilli@hotmail.com, elyhts@gmail.com, stgehlen@gmail.com
}

\section{Palavras-chave:}

Perspectiva freireana.

Tema Gerador. CTS.

Educação em ciências.

Cultura de participação.

\section{Keywords:}

Freirean perspective. Generator theme. STS. Education in sciences. Culture of participation.
Resumo: No contexto de um processo formativo de educadores de ciências do município de Santa Luzia/BA, investigaram-se as contribuições da Rede Temática na construção de um Ciclo Temático e analisou-se o papel destes no desenvolvimento da cultura de participação. Para tal, foram rediscutidas as informações obtidas durante o processo de Investigação Temática realizado no referido município, em que emergiram as seguintes categorias: a) a relação causaconsequência da cultura do silêncio e b) A cultura de participação como alternativa político-epistemológica. Dentre os resultados, destaca-se a relação cíclico-dialética entre a causa e a consequência das situações-limite, as quais se articulam às necessidades políticas e epistemológicas da organização social. Tais aspectos foram problematizados e sistematizados em um Plano de Ensino por meio do Ciclo Temático, corroborando para a efetivação da cultura de participação na educação CTS.

\begin{abstract}
In the context of a formative process of educators of sciences in the municipality of Santa Luzia/BA, the contributions of the Thematic Network in the construction of a Thematic Cycle were investigated and their role was analyzed in the development of the culture of participation. In order to do so, the information obtained during the Thematic Research process carried out in the mentioned municipality was rediscussed, in which the following categories emerged: a) the cause-consequence relationship of the culture of silence and b) The culture of participation as political-epistemological alternative. Among the results, the cyclicdialectic relationship between the cause and the consequence of the limit situations is highlighted, which are articulated to the political and epistemological needs of social organization. These aspects were problematized and systematized in a Teaching Plan through the Thematic Cycle, corroborating for the effectiveness of the culture of participation in STS education.
\end{abstract}

${ }^{1}$ Uma versão preliminar deste estudo foi apresentada no XXII Simpósio Nacional de Ensino de Física (SNEF), em 2017. 


\section{Introdução}

Alguns estudos que têm trabalhado sobre a transposição do pensamento de Paulo Freire para o contexto da Educação em Ciências, cada vez mais, apresentam releituras e aprofundamentos teórico-metodológicos sobre a Investigação Temática, para a obtenção e desenvolvimento de Temas Geradores (NERES, 2016). Com isso, o processo de investigação tem sido realizado de diversas formas, com diferentes sujeitos e em vários contextos, abrangendo a organização e sistematização de currículos, desenvolvimento de atividades didático-pedagógicas e a formação de educadores (DELIZOICOV, 1982; SÃO PAULO, 1990; SILVA, 2004; TORRES et al., 2008; SOUSA et al., 2014; CENTA; MUENCHEN, 2016; MAGALHÃES et al., 2016).

Auler e Delizoicov (2015), ao abordarem aspectos da Educação Ciência-TecnologiaSociedade (CTS), chamam atenção para o processo de Investigação Temática e ampliam a dimensão epistemológica e didático-pedagógica da Redução Temática. Os autores consideram que nesta etapa sejam colocadas em pauta as demandas e valores advindos das contradições sociais, de forma a orientar processos de produção científica e tecnológica, políticas públicas e currículos educacionais, em sintonia com as concepções de educação de Paulo Freire e do Pensamento Latino Americano em Ciência, Tecnologia e Sociedade (PLACTS). Ao problematizar esses aspectos, tem-se defendido que a sociedade possa ser incluída na tomada de decisões, efetivando a cultura de participação social (AULER, 2011; AULER; DELIZOICOV, 2015; ROSO; AULER, 2016).

Discussões em torno da questão da participação social tem sido foco de diversas pesquisas pautadas na educação CTS, no PLACTS e na concepção de educação de Paulo Freire (STRIEDER, 2012; ROSO, 2014; SANTOS, 2016; ROSA; AULER, 2016). No entender de Rosa e Auler (2016), há uma necessidade de se ampliar a abrangência da participação social postulada em alguns trabalhos, principalmente no âmbito da educação CTS, que se encontra limitada ao "pós", ou seja, "pós-definição da agenda de pesquisa, pósexecução de projetos tecnológicos" (p.205). Em busca desta participação social, destaca-se o trabalho de Centa e Muenchen (2016) que apontou para a necessidade de efetivação da cultura de participação, para a superação de uma contradição social relacionada a um rio localizado em Santa Maria/RS. Neste processo houve o desenvolvimento de uma parceria entre educadores, educandos e o poder público. Porém, ainda há necessidade de se aprofundar de que forma podem ser inseridas discussões que fomentem a cultura de participação pela Investigação Temática, em especial, em processos formativos de educadores de ciências.

Ao realizar adaptações no processo de Investigação Temática, Silva (2004) apresenta um caminho teórico-metodológico que auxilia na compreensão das relações sociais, sejam culturais e/ou econômicas, analisadas por meio da construção da Rede Temática (SILVA, 
2004; FURLAN et al., 2013; FONSECA, 2017. Além disso, algumas produções do Grupo de Estudos sobre Abordagem Temática no Ensino de Ciências (GEATEC), vinculado à Universidade Estadual de Santa Cruz (UESC), Ilhéus/BA, têm sinalizado alguns aspectos que também podem contribuir para o desenvolvimento da cultura de participação na etapa de Redução Temática. Solino (2013), por exemplo, desenvolveu um esquema cíclico contendo problematizações que auxiliam na organização de Unidades de Ensino, para a elaboração de atividades didático-pedagógicas. A partir do estudo de Magalhães (2015), a visão sobre o Ciclo foi sendo aprimorada, passando a ser denominado de Ciclo Temático, o qual foi utilizado por Novais (2015) como forma de sintetizar as visões dos educadores sobre as contradições sociais identificadas na comunidade local e escolar. Em estudo mais recente, Fonseca (2017) amplia o horizonte analítico do Ciclo e o estrutura em três dimensões, sendo elas: causas, consequências e alternativas para a superação das contradições sociais.

Neste presente trabalho, pressupõe-se que as implicações para o desenvolvimento da cultura de participação, tais como abordadas por Auler e Delizoicov (2015) no contexto da educação CTS, podem ser expressas pela Rede Temática e sistematizadas por meio das dimensões do Ciclo Temático. Assim, o objetivo deste estudo consiste em investigar as contribuições da Rede Temática na construção de um Ciclo Temático e analisar o papel destes no desenvolvimento da cultura de participação. Esse processo teve como referência a etapa da Redução Temática realizada durante um processo formativo de educadores de ciências do município de Santa Luzia/BA.

\section{A cultura do silêncio: um limite a ser superado}

Por definição, o silêncio se apresenta pela recusa ao ato de falar ou na privação das formas de comunicação, sejam elas por vias orais ou escritas (HOUAISS; VILLAR, 2004). Paulo Freire (1979), em seu livro "Conscientização", amplia a dimensão do silêncio para uma esfera mais abrangente, que se estabelece como resultado de um estado de dependência social. Nessa compreensão, o autor afirma que algumas sociedades têm determinado a produção científica e tecnológica de acordo com seus interesses ideológicos, suprimindo e silenciando as reais necessidades e valores das culturas às quais se estendem. Com isso, a modernização é vista pelo autor como um fenômeno externo, que advém da cultura dominante e se concretiza na dependência social, na manutenção de uma "cultura do silêncio".

A modernização, que reforça a cultura do silêncio, carrega consigo a invasão cultural, impedindo a autonomia do ser em sua sociedade (FREIRE, 1979). Segundo Freire (1983), toda invasão necessita da existência de um invasor que impõe e condiciona o contexto do invadido à sua própria história e cultura, reduzindo os homens a sujeitos de sua ação. $\mathrm{O}$ autor salienta que esta ação busca a conquista, a manipulação de valores sob a docilidade 
messiânica que atua no emocional dos invadidos, de modo que, invasor e invadidos estabelecem a seguinte relação:

O primeiro atua, os segundos têm a ilusão de que atuam na atuação do primeiro; este diz a palavra, os segundos, proibidos de dizer a sua, escutam a palavra do primeiro. O invasor pensa, na melhor das hipóteses, sobre os segundos, jamais com eles; estes são "pensados" por aqueles. O invasor prescreve; os invadidos são pacientes da prescrição (Ibid., p. 27).

A relação entre invasor e invadidos, que é descrita por Freire (1983), revela extremos opostos, em que os invadidos se encontram como objetos da manipulação do invasor, pois o invasor pensa sobre os invadidos, mas não com eles. A afirmação torna evidente que as intenções do invasor estão voltadas à disseminação e manutenção dos seus valores, desconsiderando as reais necessidades dos invadidos. Essa contradição limita a percepção e as ações dos sujeitos sobre sua própria realidade e, configuram-se como situações-limite, conforme Freire (1987) destaca:

Esta é a razão pela qual não são as "situações limites", em si mesmas, geradoras de um clima de desesperança, mas a percepção que os homens tenham delas num dado momento histórico, como um freio a eles, como algo que eles não podem ultrapassar. No momento em que a percepção crítica se instaura, na ação mesma, se desenvolve um clima de esperança e confiança que leva os homens a empenhar-se na superação das "situações-limites" (Ibid., p. 51).

As situações-limite também são compreendidas por Freire (1979) em uma relação entre sociedades, que é descrita da seguinte forma:

Desta maneira, a tarefa fundamental dos países sub-desenvolvidos - o compromisso histórico de seus povos - é superar sua "situação-limite" de sociedades dependentes, para converterem-se em "seres-para-si-mesmos". Sem isto estas sociedades continuarão a experiência da "cultura do silêncio", que, havendo resultado das estruturas de dependência, reforça estas mesmas estruturas (Ibid., p. 53).

Com base em Freire $(1979 ;$ 1987), as situações-limite geram uma barreia ao desenvolvimento do ser e das sociedades, criam um clima de desesperança e reforçam a perpetuação da cultura do silêncio. Em contrapartida, a percepção crítica sobre a mesma, e o reconhecimento da sociedade enquanto produtora de sua própria cultura possibilita, em uma ação coletiva, que essa barreira seja superada. Freire (1987) sinaliza no processo de Investigação Temática um caminho para identificação e superação das situações-limite, as quais caracterizam e legitimam os Temas Geradores.

Segundo Freire (1987), na medida em que se investiga, amplia-se a visão de mundo, sinalizam-se novas temáticas, enraizadas nos diferentes contextos e estruturas sociais, fonte inesgotável dos Temas Geradores. Deste modo, o autor considera que não se expressa de forma clara uma temática geradora, a própria ocultação dessa existência se configura como uma adaptação, uma situação-limite, que se manifesta de forma implícita no silenciamento dos sujeitos em face da opressão, caracterizado pelo autor como "tema do silêncio". Por isso, 
para Freire (1987), o fazer educativo tem sua origem na própria investigação do pensar do povo, como um esforço de libertação individual e coletiva, que culmina em uma ação cultural:

A investigação temática se faz, assim, um esforço comum de consciência da realidade e de autoconsciência, que a inscreve como ponto de partida do processo educativo, o da ação cultural de caráter libertador (Id., 1987, p. 57).

Ação cultural e revolução cultural supõem comunhão entre os líderes e o povo como seres que transformam a realidade. Na revolução cultural a comunhão é tão intensa que os líderes e o povo chegam a ser como um só corpo, controlado por uma permanente observação de si mesmos (Id., 1979, p. 46).

Conforme apresentado, a Investigação Temática consiste na conscientização dos sujeitos às vistas do desenvolvimento de ações individuais e coletivas que transformem a realidade. Nesse processo, a apropriação da cultura externa passa a ceder lugar para a produção de uma cultura autêntica, que valorize e reconheça as suas demandas internas (freire, 1979; 1987). Auler e Delizoicov (2015) salientam que essas demandas podem gerar novos conhecimentos e práticas, as quais estiveram silenciados pelo domínio científico e tecnológico da cultura hegemônica. É nesse contexto que os autores apontam para a necessidade da reinvenção do processo de Investigação Temática, a fim de nortear processos de produção em Ciência e Tecnologia, seguindo os pressupostos de Paulo Freire e do PLACTS.

\section{O potencial da Investigação Temática na Educação CTS}

No contexto brasileiro, alguns estudos, baseados na Educação CTS, têm buscado fundamentar-se nos pressupostos do educador Paulo Freire (STRIEDER, 2012; ROSO, AULER, 2016). Para Santos (2016), a articulação dessas duas perspectivas de ensino é uma forma de promover a transposição dos pressupostos educacionais CTS para o Brasil, considerando-se as especificidades do contexto brasileiro, visto que o movimento CTS originou-se no Hemisfério Norte, em uma realidade diferente. A articulação entre estas perspectivas de educação foi iniciada por Auler (2002), em sua tese de doutorado, por considerar que tanto os pressupostos freireanos quanto a Educação CTS buscam a participação dos sujeitos em questões sociais. Nos pressupostos freireanos essa participação é compreendida na superação da "cultura do silêncio" e, na perspectiva CTS, na superação dos modelos de decisões tecnocráticas (AULER, 2002; HUNSCHE; DELIZOICOV, 2011).

Posteriormente, Delizoicov e Auler (2011) articulam a perspectiva educacional de Paulo Freire com o PLACTS, proporcionando reflexões acerca da transferência tecnológica, do endosso a uma agenda de pesquisa única e das especificidades de cada espaço social. $\mathrm{O}$ PLACTS, "tem como orientação o enfrentamento de problemas locais/regionais, problematizando políticas científico-tecnológicas (PCT), dos países da América Latina, estruturadas a partir de demandas/necessidades de países do denominado Primeiro Mundo" 
(ROSA; AULER, 2016, p. 205). Para Dagnino (2003), o PLACTS traz à tona a necessidade de um redimensionamento da PCT da região, em consonância com as suas demandas sociais. Deste modo, os problemas localizados em uma determinada localidade, denominados de demandas sociais, passam a direcionar as PCT. De acordo com Roso e Auler (2016), o PLACTS originou-se da preocupação sobre a importação de valores ideológicos do Hemisfério Norte e de suas implicações nos direcionamentos da produção científica e tecnológica. Assim, o PLACTS busca um redirecionamento da PCT dos países latinoamericanos, por considerar que a Ciência e a Tecnologia importada não são neutras, ao contrário, são impregnadas de valores de uma sociedade hegemônica.

De modo geral, a educação CTS, a concepção de educação de Paulo Freire e o PLACTS estão em sintonia no que concerne à busca pelo desenvolvimento de uma cultura de participação. Contudo, Rosa e Auler (2016) apontam para a necessidade de se aprofundar o conceito de participação, principalmente nas pesquisas relacionadas à educação CTS, por entenderem que a participação tem sido limitada à pós-definição de agenda de pesquisa, pósexecução de projetos tecnológicos. Nesses "pós", os autores apontam que se avaliam os impactos positivos e negativos da CT na sociedade, ressaltando os aspectos positivos e atenuando os negativos, bem como uma participação pós-consumo. Essa última, no contexto educacional, pode ser exemplificada com a busca de alternativas e ações individuais, para superar o problema do lixo, reduzindo-o à reciclagem e outras ações pontuais, do tipo, não jogar lixo no chão ou plantar árvores para resolver o problema do desmatamento (AULER, N; AULER, 2015). Tendo como referência o PLACTS, Rosa e Auler (2016) sinalizam para a cultura de participação ampliada, na qual:

[...] há a necessidade de, nos processos educativos, ir além da avaliação pósprodução de CT, postulando uma reflexão sobre o direcionamento dado à atividade científico-tecnológica, sobre a agenda de pesquisa. Em outros termos, superar a linearidade que vai da Ciência-Tecnologia (CT) para a sociedade (S), na qual é comum a expressão avaliar impactos da CT na sociedade. Há a necessidade de, também, avaliar impactos da sociedade, ou setores dessa, com seus valores particulares, no direcionamento dado ao desenvolvimento científico-tecnológico (Ibid., p. 205).

Nesse contexto de questões axiológicas envolvendo a produção da CT, Santos (2016) destaca a necessidade da problematização sobre a não neutralidade da Ciência-Tecnologia, por entender que a concepção de neutralidade contribui significativamente para a permanência do modelo de decisões tecnocráticas. No entender de Strieder et al. (2016), os propósitos da educação CTS se articulam a ações sociais mais amplas relacionadas às políticas públicas, mas a maioria das ações formativas de educadores são desenvolvidas de forma pontual e com curta duração, sem ênfase nas políticas públicas. Os autores sugerem a construção de ações formativas que incorporem o papel da cultura enquanto instrumento de formação crítica e pertencimento dos sujeitos, sendo que: 
A cultura, portanto, pode ser um elo entre a demanda social macro e o contexto escolar local, ou seja, reconhecer o que caracteriza o grupo cultural regional pode ser um importante meio de fazer-se crer em sua responsabilidade histórica no mundo atual (Ibid., p. 78).

No contexto das aproximações Freire-PLACTS, Auler e Delizoicov (2015) destacam contribuições do desenvolvimento da Investigação Temática para fomentar a cultura de participação nos indivíduos e inserir tanto nos currículos escolares quanto nas agendas de pesquisa, novas demandas sociais. Deste modo:

\begin{abstract}
Entendemos que o processo de investigação temática, [...] fundamenta e instrumentaliza processos participativos que, colocando em cena novos atores, colocam em pauta novos valores, novas demandas que podem alimentar a concepção e a execução de novas agendas de pesquisa, de novas configurações curriculares (Ibid., p. 289).
\end{abstract}

Auler (2011) discute princípios a serem incorporados na educação CTS por meio dos pressupostos freireanos, por considerar que a participação da sociedade em processos decisórios deve ser uma das dimensões centrais da educação. $O$ autor destaca que é necessário:

[...] ampliar os mecanismos de participação, contribuindo com a construção de uma cultura de participação. Considerando a história, a cultura e a situação socioeconômica, participar e/ou potencializar para a participação, em processos decisórios, assume perspectivas distintas, no contexto latino americano, comparativamente aos contextos em que, no campo educacional, surge o movimento CTS. Para tal, assume-se a referida articulação Freire-CTS, considerando que a concepção freiriana de participação está enraizada em países da América Latina e do continente africano (Ibid., p.2).

Em síntese, Auler (2011), Auler e Delizoicov (2015) e Roso e Auler (2016) defendem que para ampliar a participação da sociedade em processos decisórios, isto é, na efetivação de uma cultura de participação, há necessidade de se problematizar aspectos relacionados à PCT, considerando as demandas socais de uma determinada comunidade. No contexto educacional, um caminho para que discussões deste patamar possam ser incorporadas em organizações curriculares, se dá por meio da Investigação Temática (AULER; DELIZOICOV, 2015).

A Investigação Temática (FREIRE, 1987) foi sistematizada por Delizoicov (1991) para o contexto da educação formal e consiste em cinco etapas: 1) Levantamento Preliminar: estudo da comunidade local; 2) Codificação: análise e escolha de contradições sociais vivenciadas pelos moradores da comunidade; 3) Descodificação: as situações-limites são legitimadas pela comunidade e sintetizadas em Temas Geradores; 4) Redução Temática: escolha de conceitos científicos e conteúdos necessários para a compreensão do tema e planejamento das aulas; 5) Desenvolvimento em sala de aula: implementação das atividades didático- pedagógicas em sala de aula.

Ao considerar a Investigação Temática como um caminho para a efetivação da cultura de participação (AULER; DELIZOICOV, 2015) na articulação Freire-CTS, compreende-se que os temas passam a apresentar um critério de seleção: as situações-limite de uma 
determinada comunidade. Isso porque, os Temas Geradores, em sua essência, representam a compreensão da comunidade sobre a realidade em que vivem, caracterizando suas demandas, ou seja, suas necessidades reais e concretas (FREIRE, 1987). Entretanto, Roso et al. (2015) e Roso e Auler (2016) salientam que a maioria dos trabalhos que aproximam Freire-CTS tem ocultado a essência do referencial freireano em detrimento de temas menos complexos e restritos à Ciência-Tecnologia. Roso e Auler (2016) explicam essa questão:

\begin{abstract}
Da mesma forma que Strieder (2012), identificamos que Freire é bastante citado nos artigos analisados, tanto por aproximações entre objetivos CTS e pressupostos freireanos, quanto pela filiação teórica assumida pelos autores. Porém, como apontamos, a essência do trabalho de Freire tem sido ignorada ou não explicitada nas práticas analisadas. Ou seja, a investigação temática. Não postulamos um referencial único na educação. Também não estamos defendendo que apenas práticas educativas que tenham como ponto de partida a investigação temática sejam pertinentes. Contudo, é necessário que haja coerência com os referenciais assumidos, o que parece frágil em parte dos artigos analisados, sobretudo nos que aproximam CTS e Freire, visto que ignoram o que é essencial na obra do educador. Parece que, em alguns casos, Freire é citado para camuflar práticas curriculares cristalizadas (Ibid., p. 385).
\end{abstract}

Mesmo que de forma pontual, alguns estudos têm desenvolvido aspectos do processo de Investigação Temática na obtenção de temas e discutido questões relacionadas ao PLACTS. Por exemplo, Centa e Muenchen (2016) discutem a questão do rompimento da "cultura do silêncio" e o despertar para uma cultura de participação, no contexto de atividades de ensino no desenvolvimento do tema “Arroio Cadena: Cartão Postal de Santa Maria?”. As autoras evidenciaram que atividades didático-pedagógicas sobre o tema despertaram nos educandos a vontade de mudança e estes começaram a lutar pela transformação de sua realidade, por meio de ações em parceria com o poder público na promoção de políticas públicas para revitalização do rio Arroio Cadena. Porém, Centa e Muenchen (2016) não tem como foco de análise a sistematização teórico-metodológica dessas ações no processo de Investigação Temática, especificamente, na etapa de Redução Temática.

O estudo de Silva (2004) apresenta-se como um caminho teórico-metodológico que sistematiza a complexidade das relações sociais estudadas no processo de Investigação Temática. O autor aponta que as relações entre a visão da comunidade local e os temas são representadas em forma de Rede Temática, elaborada com o objetivo de estabelecer relações parte-todo, particular-geral. Essa noção de Rede Temática é resultado de algumas adaptações realizadas por Silva (2004) na dinâmica de Investigação Temática, a exemplo da inserção do Contratema que representa uma antítese do Tema Gerador. Assim, os Contratemas sintetizam o entendimento dos educadores, a partir dos conhecimentos universais sistematizados, das situações significativas contidas nas contradições. Em resumo,

[...] as Redes Temáticas atuam como referenciais pedagógicos para o resgate constante do processo de análise crítica realizado pela comunidade escolar, em que objetos e elementos da realidade local, micro e macro social se inter-relacionam nas dimensões materiais, culturais e políticas (Ibid., p.247). 
As dimensões materiais, culturais e políticas explicitadas na Rede Temática, proposta por Silva (2004), permitem uma visão ampliada sobre as relações locais, micro e macro sociais. Isso porque, a rede permite a inter-relação das demandas e contradições identificadas - via Investigação Temática - na comunidade local, com elementos mais amplos da organização social, a exemplo de políticas públicas (SILVA, 2004; FURLAN et al., 2013). Fonseca (2017) apresenta um esquema sintético da Rede Temática (Figura 1) que auxilia a compreender sua estruturação.

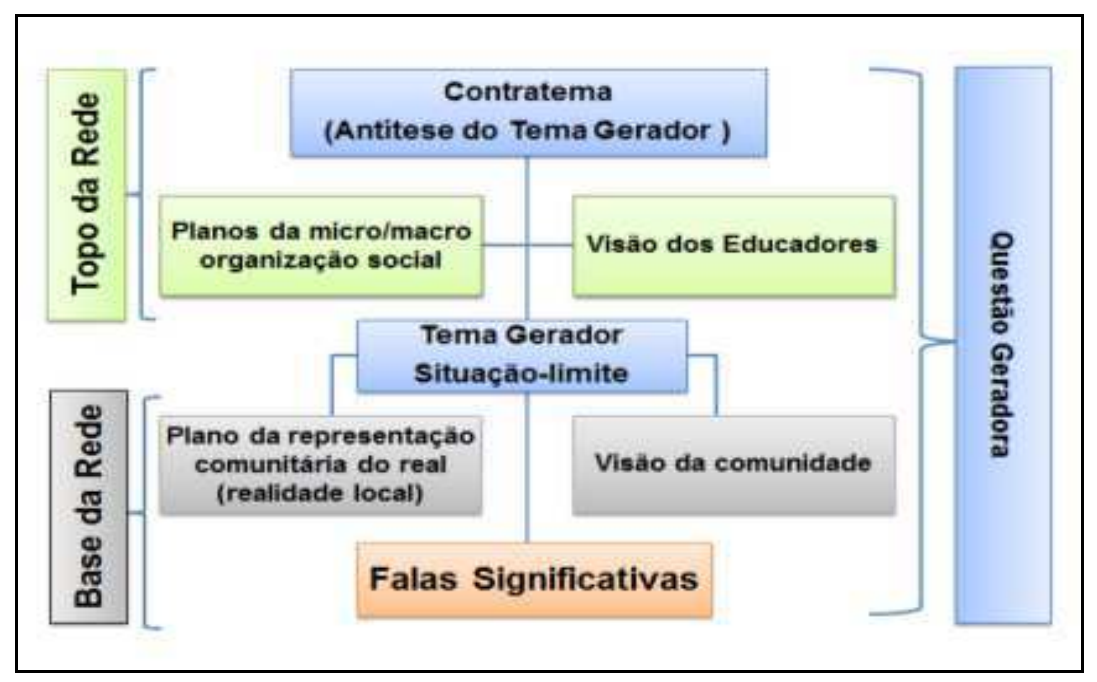

Figura 1- Síntese da Rede Temática de Silva (2004).

Fonte: Fonseca (2017, p.89).

$\mathrm{Na}$ base da rede, apresentam-se as sínteses das demandas e contradições sociais identificadas durante a investigação da comunidade local, as quais se expressam no Tema Gerador e, no topo da rede, apresenta-se a visão dos educadores sobre a realidade local articulada a elementos dos níveis micro e macro das relações/organizações sociais (SILVA, 2004; FURLAN et al., 2013; FONSECA, 2017). Entretanto, nessa inter-relação, torna-se necessário problematizar e sistematizar os aspectos relacionados ao desenvolvimento da cultura de participação.

\section{O papel do Ciclo Temático na Redução Temática}

O Ciclo Temático foi elaborado no contexto do GEATEC para sintetizar as compreensões da comunidade sobre o Tema Gerador e promover uma visão geral do Tema, para auxiliar o processo de Redução Temática. Assim, o Ciclo Temático é compreendido como um processo realizado após a elaboração da Rede Temática, com o objetivo de transpor alguns elementos da Rede Temática para a programação curricular, em especial na organização de Unidades de Ensino (NERES, 2016).

As primeiras discussões sobre o Ciclo foram realizadas por Solino (2013), que construiu um esquema cíclico, que representava uma visão geral das questões referentes ao 
tema "Rio Cachoeira: que água é essa?". Este Ciclo foi estruturado em quatro fases: i) águas do Rio Cachoeira; ii) tratamento e distribuição; iii) consumo; iv) tratamento e preservação. Cada fase tinha diversas problematizações realizadas pelos integrantes do GEATEC, que orientaram na elaboração das atividades didático-pedagógicas.

Magalhães (2015) denomina este esquema cíclico de Ciclo Temático e o utiliza para explicar as situações que representam o problema da poluição do rio Água Preta, localizado no município de Pau Brasil, destacando como possíveis soluções a participação tanto da comunidade quanto do poder público. Fonseca (2017), ao discutir o processo de obtenção do Tema Gerador "Condições da feira nossa de cada dia: bairro de Fátima, Itabuna/BA", amplia o horizonte analítico do Ciclo e ressalta suas contribuições no processo de Redução Temática:

[...] por meio do Ciclo tornou-se mais fácil selecionar os conteúdos e conceitos científicos, pois em sua construção foi preciso pensar no problema vivenciado pela comunidade nos efeitos que esse problema traz aos moradores, finalizando com possíveis alternativas para superação do problema. Ou seja, o Ciclo evidencia a causa e a consequência do problema buscando por fim discutir as possíveis alternativas referentes ao Tema Gerador (Ibid., p.93).

No Ciclo Temático construído pela autora, as causas estão relacionadas com as precárias condições da feira, em relação à qualidade dos alimentos, a presença de animais na feira e esgoto a céu aberto; nas consequências foram problematizadas as implicações dos problemas da feira para saúde e meio ambiente; e nas alternativas a autora propõe algumas ações individuais e coletivas que podem ser assumidas para o enfrentamento dos problemas causados pelas condições precárias da feira. A Figura 2 ilustra o Ciclo Temático construído por Fonseca (2017).

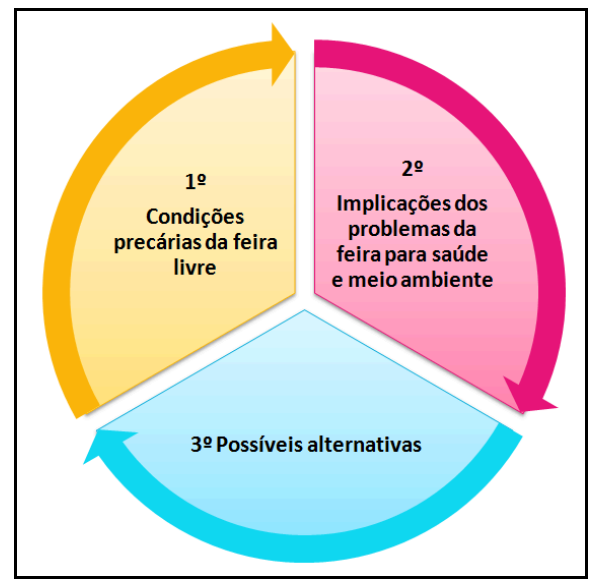

Figura 2 - Ciclo Temático das "Condições da feira nossa de cada dia: bairro de Fátima, Itabuna/BA".

Fonte: adaptado de Fonseca (2017, p. 96).

Fonseca (2017) realizou algumas adaptações no Ciclo estabelecendo uma dinâmica no âmbito das causas, consequências e possíveis alternativas necessárias à superação de situações-limite identificadas durante a investigação, tais como: passividade em relação aos problemas do bairro; falta de criticidade com relação ao descarte inadequado de lixo; 
acomodação (concepção que os problemas são naturais), entre outras. A autora evidencia novas contribuições do Ciclo, ao afirmar que este sinaliza de forma objetiva ações necessárias à superação de situações-limite referentes ao Tema Gerador. Além disso, o Ciclo passa a contribuir na sistematização das Unidades de Ensino, as quais são organizadas tendo como referência as causas, consequências e alternativas. Por exemplo, no Tema Gerador "Condições da feira nossa de cada dia: bairro de Fátima, Itabuna/BA", as seguintes Unidades foram elaboradas: Espaço sociocultural da feira; Qualidade dos alimentos e o lixo inadequado na feira; Animais na feira; e Possíveis Alternativas.

Em síntese, no contexto de processos formativos promovidos pelo GEATEC em parceria com educadores de escolas públicas da região sul da Bahia, o Ciclo Temático tem contribuído para a problematização e sistematização de aspectos relacionados ao Tema Gerador, bem como auxilia na elaboração de Unidades de Ensino. Além disso, há indicativos de que o Ciclo Temático pode inter-relacionar elementos das diferentes organizações sociais local, micro e macro da Rede Temática proposta por Silva (2004) -, em ações individuais e coletivas, a depender do nível das problematizações que forem realizadas em cada uma de suas dimensões (SOLINO, 2013; MAGALHÃES, 2015; FONSECA, 2017).

\section{Procedimentos metodológicos}

O presente estudo foi realizado em um contexto mais amplo, envolvendo um processo formativo de educadores de ciências promovido pelo GEATEC intitulado de "Organização da programação curricular do Ensino de Ciências com educadores de Santa Luzia/BA”. Esse processo formativo ocorreu no município de Santa Luzia/BA, entre os meses de junho e agosto de 2016, em 4 encontros quinzenais, totalizando 40 horas. O curso foi resultado de uma parceria do GEATEC com a Secretaria Municipal de Educação de Santa Luzia/BA, a qual o inseriu como parte da formação continuada de educadores que atuam no componente curricular de ciências no Ensino Fundamental II do município, totalizando sete educadoras². Para a realização do processo formativo foi desenvolvida a Investigação Temática (DELIZOICOV, 1991), compreendendo as seguintes etapas:

a) Levantamento Preliminar ${ }^{3}$ - realizou-se um levantamento de informações em livros, sites e blogs do município de Santa Luzia/BA e região. Também foram realizadas conversas informais com os moradores e videogravações da comunidade (ruas, avenidas, centros históricos, pontos turísticos, etc.). As informações obtidas foram reunidas pela equipe do

\footnotetext{
${ }^{2}$ As educadoras possuem diferentes formações: duas licenciadas em Pedagogia, duas licenciadas em Ciências Biológicas, uma licenciada em Letras, uma licencianda em Matemática, e uma somente com Magistério.

${ }^{3}$ A discussão teórico-metodológica do desenvolvimento dessa etapa é aprofundada no estudo de Milli, Solino e Gehlen (2018).
} 
GEATEC em grupos, de acordo com suas semelhanças semânticas, orientando a produção de um vídeo intitulado: "Bem-Vindo a Santa Luzia". Tal organização permitiu que fossem interpretadas pela equipe possíveis situações-limite vivenciadas pela comunidade.

b) Análise das situações e escolha das codificações - O vídeo foi problematizado com as educadoras pela equipe do GEATEC. Na problematização foram destacadas as principais problemáticas da comunidade sob a ótica das educadoras, as quais são moradoras do município. Dentre as problemáticas, destaca-se o uso de drogas por jovens e adolescentes, o abuso infantil, e a gravidez na adolescência. Essas problemáticas foram reorganizadas em novos grupos de informação, que foram transpostos a um portfólio, e apresentado à comunidade por meio de conversas com os moradores, educandos e integrantes de algumas instâncias da comunidade (saúde, segurança e poder público).

c) Diálogos descodificadores - a partir das informações obtidas na comunidade evidenciou-se como situação-limite à compreensão limitada dos moradores sobre as causas e consequências da violência no município de Santa Luzia, uma vez que nas falas destes e nas discussões com as educadoras foi identificada uma visão acrítica da problemática da violência no município. Além disso, pela falta de divulgação e valorização dos pontos turísticos da cidade, não são reconhecidas as alternativas de lazer, evidenciando práticas reduzidas a festas, consumo de álcool e drogas, fato que possui uma relação intrínseca com o expressivo número de acidentes de trânsito e dos altos índices de violência. Tais situações-limite legitimaram o Tema Gerador “'Lazer', violência e trânsito: roubando vidas em Santa Luzia?”.

d) Redução Temática - por meio das relações sociais que se expressam no Tema Gerador, foi elaborada com as educadoras e equipe do GEATEC a Rede Temática adaptada de Silva (2004) com base na qual foi construído o Ciclo Temático (FONSECA, 2017), que permitiu sinalizar ações, conteúdos, conceitos científicos, conhecimentos e práticas necessárias à compreensão do Tema Gerador. O Ciclo Temático orientou a elaboração do Plano de Ensino, estruturado em quatro Unidades Temáticas em que foram elaboradas 10aulas com base nos Três Momentos Pedagógicos (DELIZOICOV et al., 2011), as quais estão detalhadas no estudo de Milli (2016).

Para o desenvolvimento do presente estudo, obtiveram-se informações por meio de gravações das conversas realizadas com os moradores, educandos e funcionários - saúde, segurança, prefeitura; produções (registros em diários, planos de aula, etc.) da equipe do GEATEC e das educadoras e videogravações de todos os encontros do processo formativo. Para organizar as falas dos sujeitos, as mesmas foram representadas por uma sequência 
alfanumérica da seguinte forma: moradores - A1, A2,..., An,..., Bn e $\mathrm{Cn}^{4}$; educandos - AL1, AL2,..., ALn; grupo de educandos - ALS1, ALS2,...,ALSn; equipe do GEATEC - PG1, PG2,..., PGn; educadores - P1, P2,..., Pn; assistente social - ASS; funcionários da segurança - RSE1, RSE2,..., RSEn; funcionários da saúde - RSA1, RSA2,.., RSAn; funcionários da prefeitura - RP1, RP2,.., RPn.

As etapas de unitarização, categorização e metatexto da Análise Textual Discursiva (ATD) foram desenvolvidas durante a análise das informações obtidas no presente estudo, como proposto por Moraes e Galiazzi (2011). Deste modo, as informações obtidas foram selecionadas em unidades de sentido e reorganizadas na etapa da categorização, tendo como referência a articulação da Rede Temática (SILVA, 2004) com o Ciclo Temático (FONSECA, 2017), conforme ilustra a Figura 3:

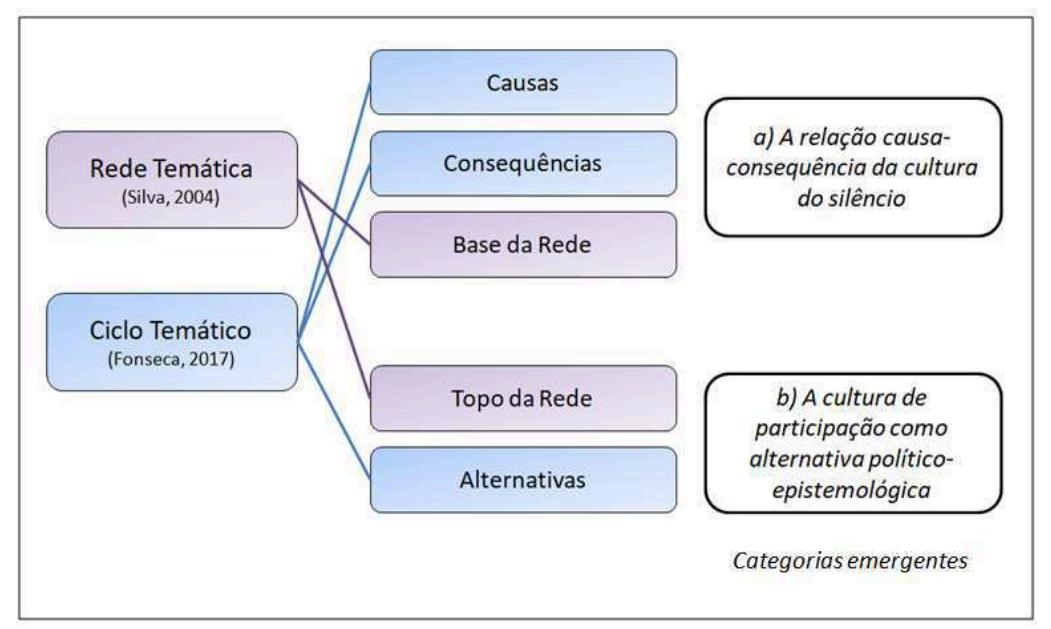

Figura 3 - Síntese do processo de categorização.

É importante destacar que a Figura 3 explicita a relação entre a Rede Temática e o Ciclo Temático, em que há elementos do Ciclo presentes na base e topo da Rede. Na base da Rede é possível observar a presença das causas e consequências das contradições sociais, as quais se expressam na visão da comunidade local e refletem aspectos da cultura do silêncio (FREIRE, 1979). No topo da Rede estão as alternativas, que se expressam a visão dos educadores sobre as problemáticas locais e sinalizam a necessidade do desenvolvimento de uma cultura de participação (AULER; DELIZOICOV; 2015). Essas relações entre a Rede e o Ciclo deram origem a duas categorias: a) A relação causa-consequência da cultura do silêncio e b) A cultura de participação como alternativa político-epistemológica. Essas duas categorias serão explicadas e exemplificadas por meio de seus metatextos nos itens a seguir.

\footnotetext{
${ }^{4}$ As conversas foram realizadas em diferentes bairros da comunidade, dos centrais aos periféricos. Para cada bairro foi atribuída uma letra e para os moradores foi atribuído um número. Por exemplo, A1 se refere ao bairro A e ao morador 1 .
} 


\section{a) A relação causa-consequência da cultura do silêncio}

Durante a quarta etapa da Investigação Temática, Redução Temática, foi elaborada a Rede Temática pelo fato dela permitir um resgate crítico da investigação que foi realizado na comunidade (SILVA, 2004). Essa rede foi estruturada pela equipe do GEATEC em colaboração com as educadoras participantes do processo formativo e foi organizada em duas partes: base e topo. A leitura e construção da rede se iniciam por sua base, que sintetiza as particularidades da comunidade local evidenciadas durante o processo de investigação, suas contradições e demandas ocultadas pelas situações-limite (SILVA, 2004; FURLAN et al., 2013; FONSECA, 2017). Essas situações são resultados de uma construção histórica e cultural, que limitam a percepção crítica dos sujeitos sobre a realidade (FREIRE, 1987). Situadas por um contexto histórico, as situações-limite se apresentam vinculadas às causas de diversas problemáticas vivenciadas pelos moradores de Santa Luzia.

Para Freire (1987), é o nível de percepção que os indivíduos têm sobre o problema que vai determinar a existência de uma situação-limite. Nesse contexto, destacam-se algumas falas que estruturam a base da rede e as relações estabelecidas pelas educadoras e equipe do GEATEC. Essas relações contribuem para a compreensão do nível de percepção dos sujeitos sobre a realidade (SILVA, 2004; FURLAN et al., 2013), conforme a Figura 4, que representa a base da Rede Temática, adaptada de Silva (2004), desenvolvida durante o processo formativo. 


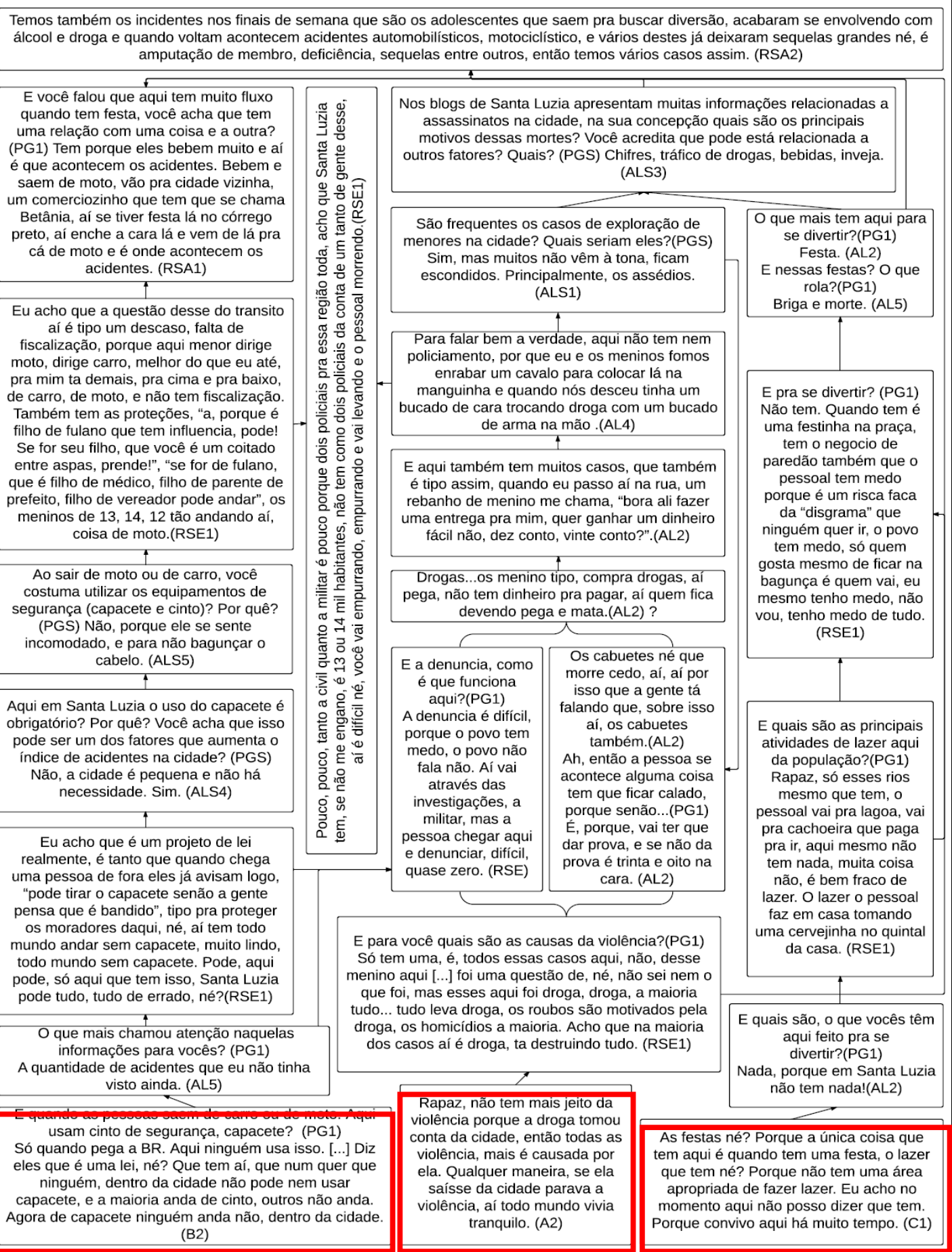

Figura 4 - Base da Rede Temática de Santa Luzia/BA, adaptada de Silva (2004).

$\mathrm{Na}$ base da Rede estão as falas que representam as concepções de mundo dos sujeitos, suas situações-limite, que se expressam nos limites explicativos dos sujeitos sobre sua própria concepção de mundo (SILVA, 2004). Para Silva (2004), essas falas são significativas, pois reproduzem as diferentes visões de mundo da comunidade. As três primeiras falas situadas na parte inferior da Figura 4, destacadas com a cor vermelha, expressam o conjunto principal de situações-limite que foram legitimadas durante o processo de Investigação Temática. A leitura dessas falas permite a visualização dos posicionamentos dos sujeitos frente às problemáticas identificadas na comunidade, bem como a inter-relação desses posicionamentos na 
organização social local (SILVA, 2004). O Quadro 1 apresenta uma síntese das falas significativas e as situações-limite associadas a elas.

Quadro 1 - Falas significativas e situações-limite associadas.

\begin{tabular}{|c|c|c|}
\hline Falas Significativas & Situações-limite & Comentários \\
\hline $\begin{array}{l}\text { Rapaz, não tem mais jeito da violência } \\
\text { porque a droga tomou conta da cidade, } \\
\text { então todas as violência, mais é causada por } \\
\text { ela. Qualquer maneira, se ela saísse da } \\
\text { cidade parava a violência, aí todo mundo } \\
\text { vivia tranquilo. (A2) }\end{array}$ & $\begin{array}{l}\text { Compreensão limitada da } \\
\text { questão da violência. }\end{array}$ & $\begin{array}{l}\text { O morador A2 não compreende que o } \\
\text { fenômeno violência apresenta relações } \\
\text { sociais complexas, de modo que, para ele, a } \\
\text { droga apresenta-se como elemento central da } \\
\text { violência. Se "ela saísse", isto é, se não } \\
\text { houvesse consumo e/ou tráfico, não haveria } \\
\text { mais problemas de violência no município. }\end{array}$ \\
\hline $\begin{array}{l}\text { As festas né? Porque a única coisa que tem } \\
\text { aqui é quando tem uma festa, o lazer que } \\
\text { tem né? Porque não tem uma área } \\
\text { apropriada de fazer lazer. Eu acho no } \\
\text { momento aqui não posso dizer que tem. } \\
\text { Porque convivo aqui há muito tempo. (C1) }\end{array}$ & $\begin{array}{l}\text { Não reconhecimento de } \\
\text { alternativas de lazer por } \\
\text { parte da população. }\end{array}$ & $\begin{array}{l}\text { O morador C1 não reconhece alternativas de } \\
\text { lazer na comunidade que não sejam as festas, } \\
\text { desconsiderando o patrimônio natural, } \\
\text { histórico e cultural presente no município. }\end{array}$ \\
\hline $\begin{array}{l}\text { E quando as pessoas saem de carro ou de } \\
\text { moto. Aqui usam cinto de segurança, } \\
\text { capacete? (PG1) Só quando pega a BR. } \\
\text { Aqui ninguém usa isso. [...] Diz eles que é } \\
\text { uma lei, né? Que tem aí, que num quer que } \\
\text { ninguém, dentro da cidade não pode nem } \\
\text { usar capacete, e a maioria anda de cinto, } \\
\text { outros não anda. Agora de capacete } \\
\text { ninguém anda não, dentro da cidade. (B2) }\end{array}$ & $\begin{array}{lll}\text { Percepção acrítica } & \text { da } \\
\text { necessidade do uso } & \text { de } \\
\text { equipamentos } & \text { de } \\
\text { segurança. } & \end{array}$ & $\begin{array}{l}\text { A fala de B2 revela que a maioria da } \\
\text { população do município não faz uso dos } \\
\text { cintos de segurança e/ou capacetes atribuindo } \\
\text { a uma suposta lei municipal. Tal fato } \\
\text { caracteriza uma percepção acrítica, uma vez } \\
\text { que ele percebe que o problema existe, mas } \\
\text { não o reconhece de fato como um problema. }\end{array}$ \\
\hline
\end{tabular}

A interpretação das falas da comunidade foi realizada pela equipe do GEATEC em colaboração com as educadoras. O olhar das educadoras, enquanto moradoras da comunidade e cidades circunvizinhas, permite uma visão mais próxima da realidade investigada. Nessa relação, dentre as problemáticas de trânsito, destacam-se os questionamentos realizados pela equipe do GEATEC a um grupo de alunos, os quais relatam sobre a utilização de equipamentos de segurança na condução de veículos no município, conforme as falas:

Ao sair de moto ou de carro, você costuma utilizar os equipamentos de segurança (capacete e cinto)? Por quê? (GEATEC)

[...] não, porque ele se sente incomodado, e para não bagunçar o cabelo. (ALS5).

Aqui em Santa Luzia o uso do capacete é obrigatório? Por quê? Você acha que isso pode ser um dos fatores que aumenta o índice de acidentes [com morte] na cidade? (GEATEC).

Não, a cidade é pequena e não há necessidade. Sim. (ALS4).

A fala do grupo ALS5 evidencia a banalização do uso do capacete, a ponto de colocar em risco sua própria segurança no trânsito. O grupo ALS4 apresenta uma visão acrítica e contraditória, uma vez que ao mesmo tempo em que eles afirmam não haver a necessidade do uso do capacete, fazem a relação com o alto índice de mortalidade. Outra fala que se destaca é a de um funcionário da segurança local, que responde sobre o porquê das pessoas não fazerem o uso de equipamentos de segurança: 
Eu acho que é um projeto de lei realmente, é tanto que quando chega uma pessoa de fora eles já avisam logo, 'pode tirar o capacete senão a gente pensa que é bandido', tipo pra proteger os moradores daqui, né, aí tem todo mundo andar sem capacete, muito lindo, todo mundo sem capacete. Pode, aqui pode, só aqui que tem isso, Santa Luzia pode tudo, tudo de errado, né?(RSE1).

A fala do funcionário da segurança RSE1 revela que quando os moradores se protegem da criminalidade deixam de se proteger no trânsito, sugerindo que existe um projeto de lei que veta a utilização do capacete no município. Diversos moradores também destacam a existência dessa suposta lei municipal e, por conta disso, justificam o não uso de tais equipamentos de segurança. A equipe do GEATEC buscou informações na prefeitura do município sobre a existência dessa lei, na qual um funcionário da prefeitura relata:

[...] eu consultei, a câmara [municipal de vereadores] disse que houve realmente uma discussão sobre esse assunto, devido ao número, num período aqui, que tinha muito assalto, todos eram com motoqueiro com o capacete. Então a solução no momento, levada para câmara, chegaram a discutir, mas depois não aprovaram, não ficou em lei, ficou em discussão. (RP1).

Em relação às falas dos educandos e do funcionário da segurança local, as implicações das problemáticas sociais, entre a violência e o trânsito, expressam uma relação entre causa e consequência das dimensões do Ciclo Temático. Desta maneira, a consequência da violência é uma das causas (não direta) para o não uso dos equipamentos de segurança de trânsito, em outras palavras, uma das causas para as pessoas não usarem capacetes quando se transportam em motocicletas é o medo à violência do município.

As discussões em torno dessas problemáticas podem implicar em ações que se limitam às consequências dos reais problemas, a exemplo da criação de uma lei que proíbe a utilização de capacetes discutida por RP1. Essas ações se assemelham ao fenômeno do "pós-produção", que consiste apenas em avaliar os impactos, as consequências da Ciência e da Tecnologia, desconsiderando os valores que as direcionam (ROSA; AULER, 2016). Outras situações apresentadas por um funcionário da segurança e educandos também evidenciaram questionamentos de natureza complexa, como é destacado:

\footnotetext{
E a denúncia [dos casos de violência], como é que funciona aqui? (PG1)

A denúncia é difícil, porque o povo tem medo, o povo não fala não. (RSE)

Os cabuetes ${ }^{5}$ né que morre cedo, aí por isso que a gente tá falando que, sobre isso aí, os cabuetes também. (AL2)

Ah, então a pessoa se acontece alguma coisa tem que ficar calado, porque senão... (PG1)

É, porque, vai ter que dar prova, e se não da prova é trinta e oito na cara. (AL2).
}

Strieder (2012) chama a atenção para a dialogicidade e problematização da perspectiva freireana como forma de promover a cultura de participação. No entanto, o nível de complexidade das situações destacadas é um desafio, uma vez que o silenciamento dos sujeitos, em especial na fala de AL2, é caracterizado pela eminência da morte. Reconhecer a

\footnotetext{
${ }^{5}$ Termo atribuído a pessoas fofoqueiras.
} 
complexidade entre as causas e consequências dessas problemáticas implica em ampliar o nível dessas problematizações para que a participação social não se limite ao nível do "pósprodução" (ROSA; AULER, 2016). Assim, por exemplo, antes de sinalizar a denúncia como uma solução para os problemas de violência da comunidade, deve-se questionar sobre o porquê dela não ocorrer, isto é, quais fatores silenciam os sujeitos impedindo o diálogo e a participação.

Ao problematizar as dimensões das causas e consequências das problemáticas vivenciadas no município de Santa Luzia, as falas evidenciam que a violência também influencia nas atividades e visões da comunidade sobre o lazer e diversão, como é destacado:

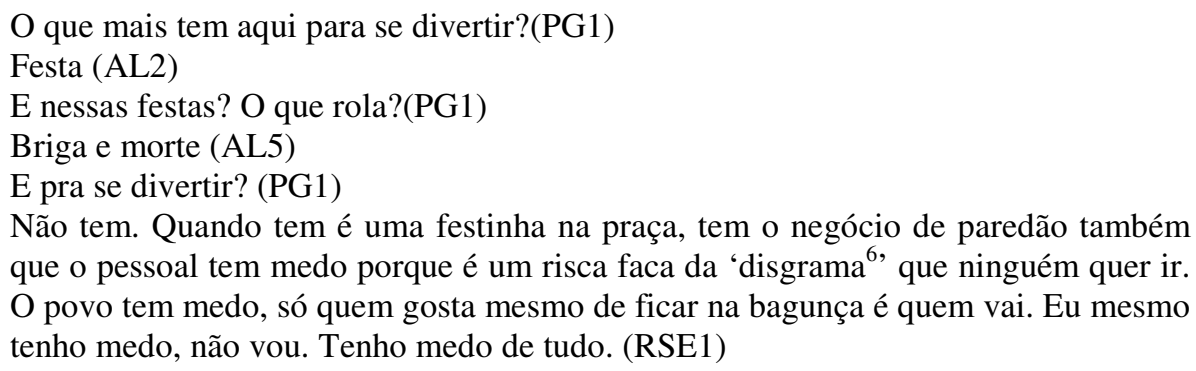

As festas são destacadas pelos educandos AL2 e AL5 e o funcionário da segurança RSE1 como a única alternativa de lazer e diversão, e são marcadas por atos de violência. As falas revelam que os moradores não reconhecem e/ou não valorizam os pontos turísticos do município, considerando que Santa Luzia possui rios, lagoas, cavernas e monumentos históricos, compreendendo parte da zona turística da Costa do Cacau (REHDER, 2008). Sendo assim, questiona-se: Quais as concepções desses moradores sobre lazer e diversão? Qual o papel da mídia nessa relação? Quais valores direcionam a cultura local e regional? A fala do funcionário da saúde RSA1 ajuda a esclarecer alguns desses questionamentos, de modo que:

Temos também os incidentes nos finais de semana que são os adolescentes que saem pra buscar diversão e acabam se envolvendo com álcool e droga e quando voltam acontecem acidentes automobilísticos, motociclístico, e vários destes já deixaram sequelas grandes. É amputação de membro, deficiência, sequelas entre outros. Então temos vários casos assim. (RSA2)

A fala de RSA1 foi escolhida pelas educadoras e equipe do GEATEC para compor parte de cima da base da Rede Temática, uma vez que ela sintetiza as relações complexas entre as principais causas e consequências das problemáticas identificadas no município de Santa Luzia. Assim, as situações-limite expressas na parte de baixo da base da rede (Quadro 1), foram sintetizadas na "compreensão limitada das causas e consequências da violência no município de Santa Luzia/BA", uma situação-limite da comunidade, em que não se reconhece os aspectos da organização social (SILVA, 2004; FURLAN et al., 2013) que expressam e

\footnotetext{
${ }^{6}$ Expressão regional que significa: coisa ruim; um tipo de xingamento.
} 
configuram a violência no município. Essa situação-limite legitima um Tema Gerador, nomeado pelas educadoras como “'Lazer”, Trânsito e Violência: Roubando vidas em Santa Luzia/BA?". O questionamento apresentado no tema enfatiza a complexidade da relação entre causa e consequência como parte de um fenômeno mais amplo. Em outras palavras, a causa não se apresenta diretamente relacionada com a consequência, pois existem fatores históricos e culturais que caracterizam as situações-limite.

O questionamento do Tema Gerador de Santa Luzia, ao expressar a complexidade da situação-limite da comunidade, caracteriza demandas de ordem escolar, política e social e requer ações tanto no âmbito individual quanto coletivo. A escola, por meio da educação libertadora, pode abordar valores e formar agentes de mudanças sociais, mas só isso não é suficiente, o poder público precisa também desenvolver ações concretas. Visto que este é um tema complexo e, conforme é destacado por Strieder et al. (2016), as ações formativas balizadas na educação CTS se articulam a ações sociais mais amplas relacionadas às políticas públicas, uma vez que esta é uma demanda intrínseca dos próprios propósitos dessa perspectiva de ensino.

O fenômeno da pós-produção atua na esfera da consequência, avaliando apenas os impactos da Ciência e da Tecnologia para a sociedade (ROSA; AULER, 2016). Problematizar as causas desse fenômeno implica em reconhecer os direcionamentos da PCT, os quais, na maioria dos casos, apresentam-se desvinculados das demandas da comunidade local. O fenômeno do "pós", não necessariamente vinculado à PCT, também pode influenciar no desenvolvimento das leis e políticas públicas, como o desenvolvimento de uma "lei que proíbe o uso de capacetes", conforme foi identificada em Santa Luzia. Esses aspectos podem contribuir para a manutenção de determinados problemas sociais, limitando as ações necessárias ao seu reconhecimento e enfrentamento de um determinado problema.

É nesse sentido que as falas, que estão na base da Rede Temática, suscitam um leque muito maior de perguntas do que de respostas. Por exemplo, por que os moradores não reconhecem as alternativas de lazer? Será que o conceito de lazer não está vinculado ao que a mídia expõe? Por que é comum o consumo de bebidas alcoólicas? Será que não há uma disseminação de valores que pregam e banalizam o consumo de álcool e drogas? Por que não existe a denúncia? Chama-se a atenção para o fato de que a "a cultura do silêncio" (FREIRE, 1979) está em uma esfera macro. Isso é importante ressaltar porque ela é um fenômeno superestrutural, que se estabelece em uma relação entre sociedades, mas, de algum modo ela se reflete no local, principalmente na falta de autonomia dos sujeitos, da participação e da elaboração de políticas públicas (FREIRE, 1979; 1987).

Em síntese, a depender do posicionamento dos sujeitos frente à realidade concreta, há indicativos de que as situações-limite apresentam-se como causas e consequências de 
determinados problemas sociais, pois geram e são geradas por problemas sociais. $\mathrm{Na}$ estruturação do Ciclo Temático, as causas estão diretamente relacionadas aos problemas sociais que configuram as situações-limite e as consequências às implicações sociais dessas situações. A título de análise, no desenvolvimento do processo formativo, as educadoras e a equipe do GEATEC sistematizaram um conjunto de possíveis "Causas do Problema" que representam a "A falta de Conscientização/Orientação", e o conjunto de " "Consequências" em que constam aspectos relacionados à "Falta de expectativa de Vida", tal como ilustra a Figura 5.

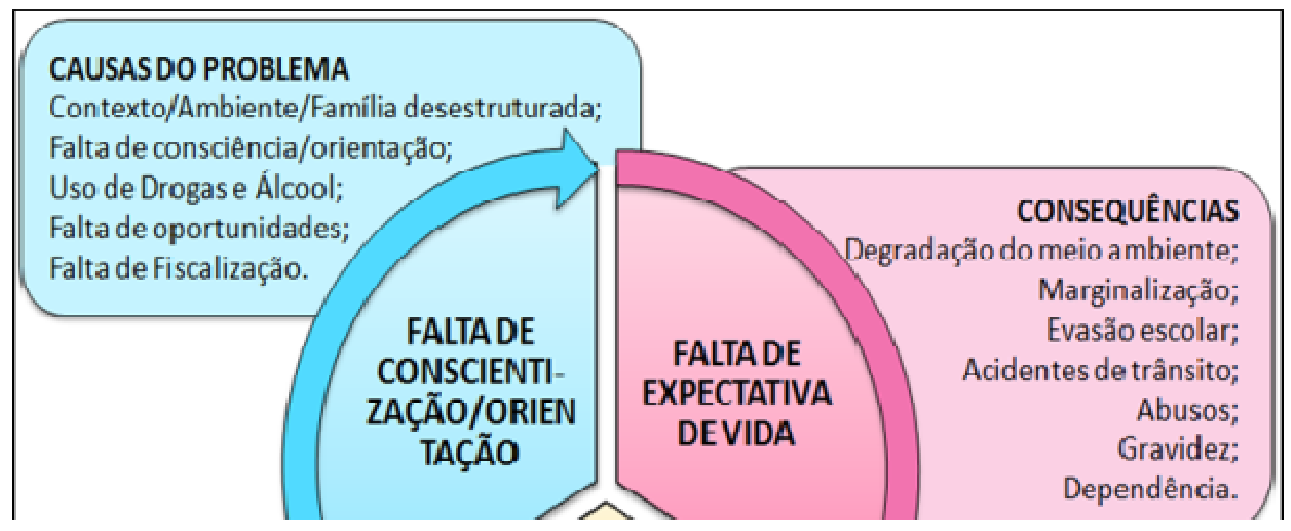

Figura 5 - Diagrama inicial do Ciclo Temático com suas causas e consequências.

Esse diagrama (Figura 5) auxilia a compressão das causas e consequências das problemáticas do município de Santa Luzia, as quais se constituem como parte de uma relação cíclico-dialética, parte de um fenômeno superestrutural que influencia e direciona as atividades locais. Assim, como relacionar essas problemáticas com fenômenos mais amplos? Como sistematizar essas relações e superá-las? É neste sentido, que além de favorecer a organização das Unidades de Ensino e do conteúdo programático (SOLINO, 2013; MAGALÃES, 2015; MILLI, 2016; NERES, 2016; FONSECA, 2017), o Ciclo Temático permite desvelar um horizonte de possibilidades para a superação das contradições sociais, conforme apresentado no próximo item.

\section{b) A cultura de participação como alternativa político-epistemológica}

De acordo com Freire (1987), o desenvolvimento da Redução Temática caracteriza-se como um estudo sistemático e interdisciplinar, em que os Temas Geradores serão analisados sob as diferentes áreas do conhecimento, em um quadro geral das ciências. Com isso, o autor ressalta que a análise não pode se limitar as especificidades de um determinado campo do saber, pois se perderia o sentido de expressão de totalidade da comunidade investigada, conforme é sinalizado: 
Desta forma, os temas que foram captados dentro de uma totalidade, jamais serão tratadas esquematicamente. Seria uma lástima se, depois de investigados na riqueza de sua interpenetração com outros aspectos da realidade, ao serem "tratados", perdessem esta riqueza, esvaziando-se de sua força, na estreiteza dos especialismos (FREIRE, 1987, p.66).

Considerando a totalidade e a interpenetração de aspectos com a realidade que caracteriza os Temas Geradores, a equipe do GEATEC e as educadoras elaboraram o topo da Rede Temática de Santa Luzia, tendo como referência os apontamentos de Silva (2004) e Furlan et al. (2013). Na visão dos autores, essa construção permite a leitura crítica sobre os elementos organizacionais locais, para então estabelecerem-se relações socioeconômicas e socioculturais mais amplas, com aspectos microssociais (regionais) e macrossociais (globais). Desse modo, é caracterizada a visão dos educadores sobre as contradições e demandas sociais, as quais se resumem no Contratema (SILVA, 2004; FURLAN et al., 2013), o qual no processo formativo foi denominado de: "ConscientizAção individual e coletiva para a redução da violência em Santa Luzia/BA”.

Devido à complexidade das causas e consequências das problemáticas sociais identificadas em Santa Luzia, as educadoras expressaram a necessidade da participação de uma assistente social do município para a construção do topo da Rede Temática (Figura 6), que foi solicitada junto à Secretaria de Saúde do referido município.

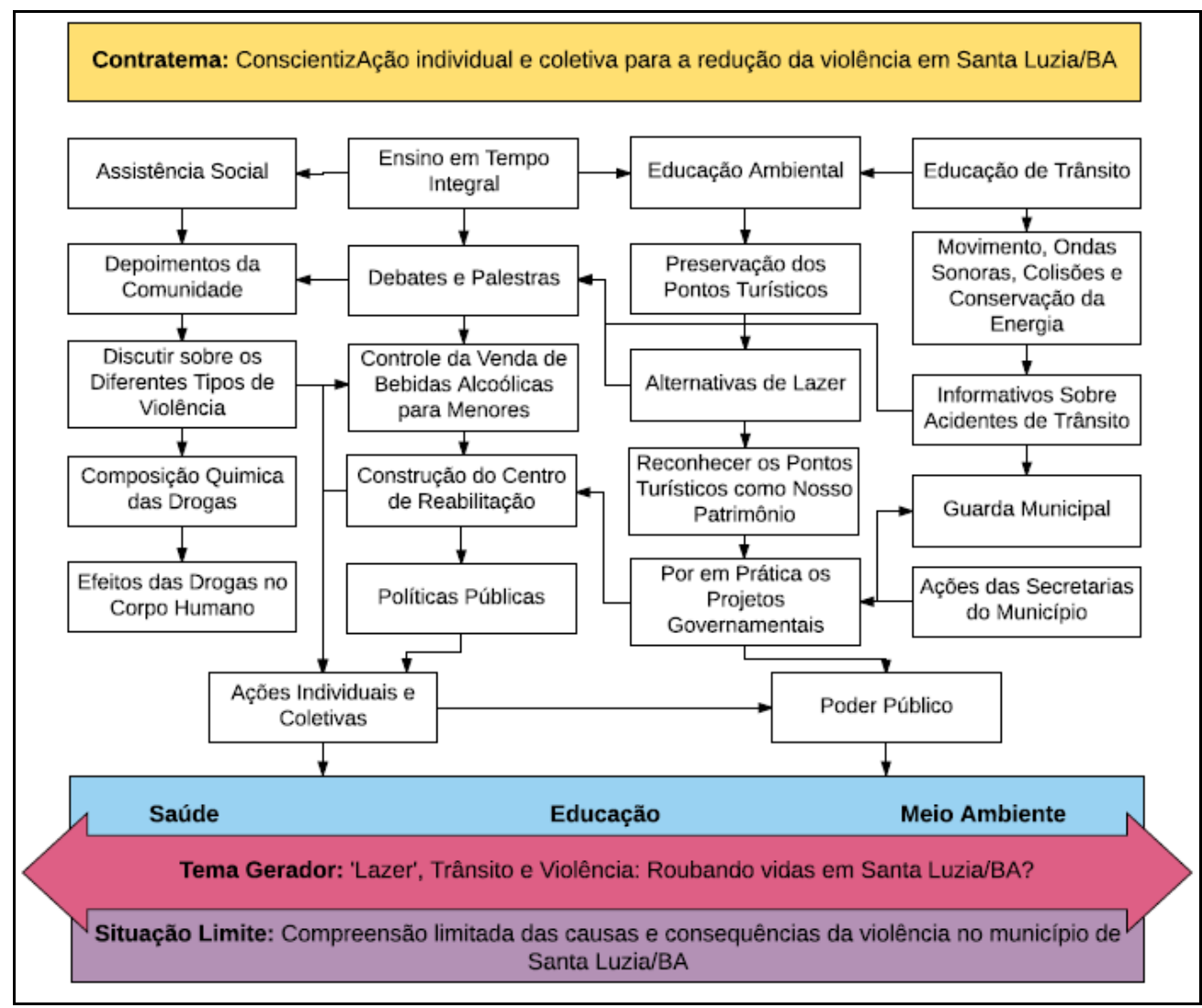

Figura 6 - Topo da Rede Temática de Santa Luzia/BA, adaptada de Silva (2004). 
Observa-se no topo da Rede Temática (Figura 6) que além dos conteúdos e conceitos científicos, existe a presença de aspectos relacionados a ações sociais que podem ser desenvolvidas tanto no âmbito individual quanto no coletivo e também na esfera do poder público. Essas ações configuram a "visão dos educadores" sobre as problemáticas locais (SILVA, 2004; FONSECA, 2017), em que se buscou valorizar as demandas da população de Santa Luzia para então inseri-las no currículo escolar (AULER; DELIZOICOV, 2015; CENTA; MUENCHEN, 2016; ROSO; AULER, 2016).

Nesse processo, discutiu-se com as educadoras e a assistente social as alternativas aos problemas do município, conforme o diálogo:

PG1, a gente está falando aqui, "estimular a cultura de participação". (P2).

Por que não deixar "desenvolvimento" [da culta de participação]? (P4).

Por que se já está ali é porque não tem a cultura de participar, né? Se não tem por quê? Porque não desenvolve ou porque não é estimulada? (ASS).

Você pode desenvolver algo que não existe, em Santa Luzia já tem a cultura de participação, só que não tem o estímulo nesse direcionamento (PG1).

Não tem o estímulo, isso! Quando pensei nisso, eu pensei nos tapetes que a gente faz de Corpus Christi, já tem [a cultura], mas nem toda a comunidade é estimulada, né?(ASS).

A assistente social ASS destacou a necessidade de se estimular a cultura de participação no município por vias críticas, uma vez que a mesma identifica o compromisso social da comunidade no desenvolvimento de certas atividades, especificamente no que tange as práticas de cunho religioso. Com isso, não desmerecendo o papel social dessas ações e, inclusive, salientando o seu valor, defende-se que esta participação seja ampliada, para que não ocorra somente uma "pseudoparticipação" (AULER; DELIZOICOV, 2015). Em outras palavras, é necessário que a comunidade possa reconhecer as implicações sobre as causas e consequências das problemáticas locais para, por meio delas, buscar e direcionar alternativas ao seu enfrentamento, conforme Freire (1983) orienta:

Sendo assim, impõe-se que tenhamos uma clara e lúcida compreensão de nossa ação, que envolve uma teoria, quer o saibamos ou não. Impõe-se que, em lugar da simples "doxa" em tôrno da ação que desenvolvemos, alcancemos o "logos" de nossa ação. (Ibid., p. 25).

Assim, o autor exemplifica a relação humanística do conhecimento científico (logos) com a opinião (doxa):

Pelo contrário, o humanismo que se impõe ao trabalho de comunicação entre técnicos e camponeses no processo da reforma agrária, se baseia na ciência, e não na "doxa", e não no "eu gostaria que fôsse" ou em gestos puramente humanitários. (Ibid., p. 50).

Nesse contexto, Freire (1983) reforça a valorização do conhecimento científico, historicamente constituído, para o desenvolvimento de ações concretas, ou seja, desvinculadas das ações meramente assistencialistas. Porém, o autor ressalta que esse processo não consiste em uma substituição do conhecimento dos sujeitos por "técnicas elaboradas", pensar assim 
seria um equívoco, pois se trata de "um problema antropológico, epistemológico e também estrutural” (Ibid., p.20). Algumas questões identificadas no município de Santa Luzia revelam essa interface do problema, em que os conhecimentos científicos, por si só, não são suficientes para resolverem as problemáticas, dada a complexidade das situações que envolvem outros aspectos, a exemplo da fala do educando AL2, em que o silêncio é uma forma de sobrevivência. Deste modo, quais seriam as alternativas para superar essas contradições?

Para Silva (2004), uma das formas de se problematizar a realidade concreta, para que ocorram as superações das contradições sociais, é por meio das questões geradoras. Essas questões, de acordo com o autor, são como uma bússola pedagógica que orienta a elaboração de algumas respostas para as problemáticas locais, articulando diferentes conhecimentos e práticas em um contraponto entre o Tema Gerador e o Contratema. Dessa forma, a equipe do GEATEC elaborou a seguinte questão geradora: "Qual o retrato da violência em Santa Luzia/BA?". Nessa questão, a definição de "retrato" foi vinculada ao sentido da descrição precisa (HOUAISS; VILLAR, 2004), isso porque:

[...] a questão geradora como interface político-epistemológica e sociocultural procura enunciar de forma problematizadora as tensões entre os conhecimentos presentes nas duas visões de mundo, esclarecendo, por um lado, as necessidades e os conflitos limítrofes vivenciados e, por outro, as contradições sociais sobre as quais essas necessidades e conflitos se assentam. (SILVA, 2004, p. 244).

A questão geradora de Santa Luzia parte da compreensão limitada das causas e consequências da violência no município às vistas da percepção crítica dessa problemática, tendo por referência os conhecimentos e práticas historicamente estabelecidos. Assim, essa questão se concretiza no reconhecimento das tensões entre estes conhecimentos, na dimensão político-epistemológica, em que se efetiva a cultura de participação (SILVA, 2004; AULER; DELIZOICOV, 2015).

A questão geradora "Qual o retrato da violência em Santa Luzia/BA?" sintetiza o Ciclo Temático, sob a ótica das causas, consequências e possíveis alternativas para superação dessa problemática na região, assim como as demais demandas sociais identificadas durante o processo de Investigação Temática. A Figura 7 apresenta o diagrama completo do Ciclo Temático constituído dos seguintes aspectos: Causas do problema: de forma geral, as problemáticas locais são causadas pela falta de conscientização/orientação decorrente do contexto social, falta de estruturação familiar, uso de álcool, falta de fiscalização e de oportunidades; Consequências: ressalta-se a falta de expectativa de vida que culmina na degradação do meio ambiente, marginalização, etc; Alternativas: aponta-se para a necessidade de se estimular a cultura de participação, em que possam ser realizadas atividades que envolvem, por exemplo, a promoção de ações e parcerias com o poder público. 


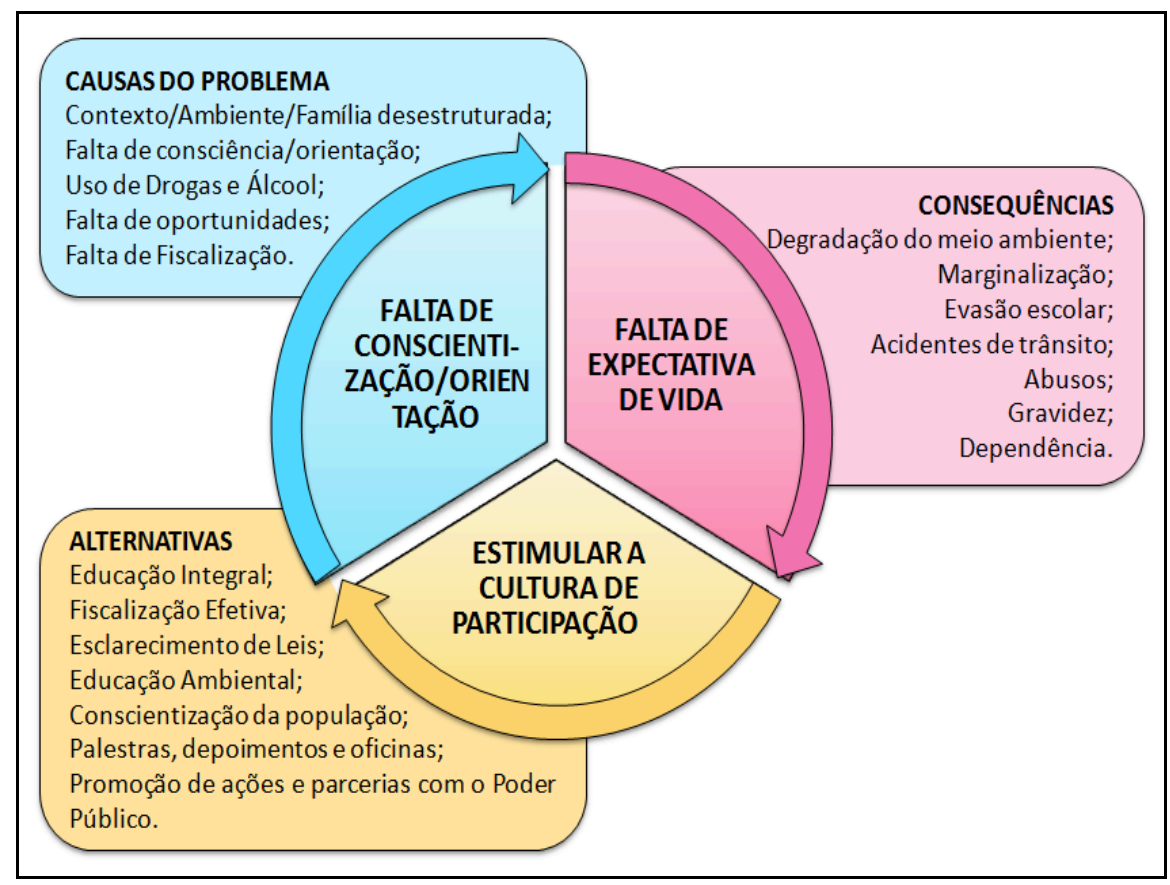

Figura 7 - Ciclo Temático desenvolvido com os educadores de Santa Luzia/BA.

Os elementos constituintes do Ciclo Temático - causas, consequências e alternativas direcionaram a elaboração das seguintes Unidades de Ensino: Meio ambiente; Violência; Drogas e Trânsito, que sistematizaram o Plano ${ }^{7}$ de Ensino (Quadro 2), a ser implementado no Ensino Fundamental II. As Unidades foram orientadas por falas de moradores, funcionários (da saúde, da segurança, etc.) e educandos, que expressam as situações significativas da comunidade (SILVA, 2004).

Quadro 2 - Plano de Ensino preliminar desenvolvido com os educadores de Santa Luzia/BA.

\section{PLANO DE ENSINO DO TEMA GERADOR: \\ “"Lazer', Trânsito e Violência: Roubando vidas em Santa Luzia?"}

\section{FALAS QUE ORIENTARAM A ELABORAÇÃO DAS UNIDADES I e II}

E quais são [as atividades de lazer], o que vocês têm aqui feito pra se divertir? (PG1) Nada, porque em Santa Luzia não tem nada! (AL2).

\section{UNIDADE - MEIO AMBIENTE}

Conteúdos e conceitos científicos:

Contexto histórico dos pontos turísticos de Santa Luzia; degradação dos pontos turísticos; descarte do lixo/agentes poluentes.

\section{Atividades:}

Visitas aos pontos turísticos da cidade; construção de um roteiro turístico; elaboração de um plano de revitalização e acessibilidade aos pontos turísticos; oficina sobre Educação Ambiental.
Rapaz, não tem mais jeito da violência porque a droga tomou conta da cidade, então todas as violência, mais é causada por ela. Qualquer maneira, se ela saísse da cidade parava a violência, aí todo mundo vivia tranquilo (A2).

\section{UNIDADE - VIOLÊNCIA}

Conteúdos e conceitos científicos:

Tipos de violências (simbólica, física, abusos, etc.); corpo humano; educação sexual (gravidez, aborto, etc.).

Atividades:

Palestras (Psicólogo, Assistente Social, Conselho Tutelar); confecção de Informativos sobre educação sexual e violência.

\footnotetext{
${ }^{7}$ Um aprofundamento do Plano de Ensino consta em Milli (2016).
} 


\section{FALAS QUE ORIENTARAM A ELABORAÇ̃̃O DAS UNIDADES III e IV}

E para você quais são as causas da violência? (PG1) Só tem uma, é, todos esses casos aqui, não, desse menino aqui [...] foi uma questão de, né, não sei nem o que foi, mas esses aqui foi droga, droga, a maioria tudo... tudo leva droga, os roubos são motivados pela droga, os homicídios a maioria. Acho que na maioria dos casos aí é droga, ta destruindo tudo (RSE1).

\section{UNIDADE - DROGAS}

Conteúdos e conceitos científicos:

Drogas lícitas e ilícitas; composição das drogas e reações químicas; efeitos biológicos.

\section{Atividades:}

Mesa redonda com funcionários da saúde (médicos, enfermeiros, etc.); pesquisa sobre as implicações políticas, econômicas e sociais das drogas; elaboração de cartazes ou banners sobre o efeito das drogas (no organismo e na sociedade).
E quando as pessoas saem de carro ou de moto. Aqui usam cinto de segurança, capacete? (PG1) Só quando pega a BR. Aqui ninguém usa isso. [...] Diz eles que é uma lei, né? Que tem aí, que num quer que ninguém, dentro da cidade não pode nem usar capacete, e a maioria anda de cinto, outros não anda. Agora de capacete ninguém anda não, dentro da cidade (B2).

\section{UNIDADE - TRÂNSITO}

Conteúdos e conceitos científicos:

Movimento e colisões; conservação da energia; equipamentos de segurança; leis de trânsito; poluição sonora.

\section{Atividades:}

Palestra: educação no trânsito; mesa redonda sobre a "Lei seca"; elaboração de propostas de lei de trânsito; confecção de informativos. Elaboração de ações e medidas necessárias para melhorar a segurança no trânsito em Santa Luzia.

Desta forma, na Unidade I se evidencia a falta de reconhecimento de alternativas para o Lazer, em que a mesma foi planejada a fim de reconhecer e valorizar os pontos turísticos e as riquezas naturais da comunidade, como as cachoeiras, lagoa de água cristalina, formações rochosas, grutas, etc. As Unidades II e III foram planejadas a fim do reconhecimento de que a violência não se resume as drogas e que existem diversos tipos e fatores que a influenciam, porém, de forma mais específica, a Unidade III trata da questão da droga no município que é citada pela maioria dos moradores e funcionários da saúde. A Unidade IV tem como foco o não reconhecimento da necessidade do uso de equipamentos de segurança.

Em síntese, as Unidades de Ensino, apresentadas no Plano de Ensino do Tema Gerador de Santa Luzia, reproduzem as dimensões das causas e consequências e alternativas presentes no Ciclo Temático (FONSECA, 2017). Por um lado, caracterizam-se os conteúdos e conceitos científicos necessários à compressão das situações-limites e, por outro, as atividades e ações que possibilitem a superação das situações-limites e a transformação da realidade local (SILVA, 2004). Com isso, revela-se a interface político-epistemológica da questão geradora (SILVA, 2004) que se concretiza na necessidade do desenvolvimento da cultura de participação (AULER, 2011; AULER; DELIZOICOV; 2015).

\section{Considerações finais}

No presente estudo, no âmbito de um processo formativo de educadores de ciências do município de Santa Luzia, investigaram-se as contribuições da Rede Temática na construção de um Ciclo Temático e analisou-se o papel destes no desenvolvimento da cultura de participação. Para tal, foi necessário rediscutir questões relativas ao levantamento de informações, análise e escolha das situações representativas das problemáticas sociais, 
definição das demandas sociais presentes na comunidade e na busca por possíveis alternativas a essas demandas. Nesse contexto, a rediscussão dessas questões só foi possível por conta da anterior realização do processo de Investigação Temática (FREIRE, 1987; DELIZOICOV, 1991).

Problematizar os aspectos necessários ao desenvolvimento da cultura de participação implica em reconhecer a gênese dos problemas e das demandas sociais, uma vez que as pesquisas que enfatizam essa discussão, em sua maioria, têm se restringindo à esfera da consequência, propondo ações vinculadas a "pós-produção" (ROSA; AULER, 2016). Este estudo evidencia que, em uma organização social, as causas de uma determinada problemática se encontram inter-relacionas às consequências de outras ações, isto quando caracterizadas por meio das situações-limite (FREIRE, 1987). Em função disso, o Ciclo Temático expressa uma relação cíclico-dialética entre causa e consequência, a qual se estabelece nas diferentes esferas da estrutura social - local, regional e global (SILVA, 2004; FURLAN et al., 2013).

Ao propor alternativas para a superação das contradições sociais de Santa Luzia, evidenciou-se por meio da terceira dimensão do Ciclo Temático, a interface políticoepistemológica da questão geradora (SILVA, 2004), a qual articula o conhecimento sistematizado a ações de ordem política que foram atribuídas à necessidade do desenvolvimento da cultura de participação social (AULER, 2011; AULER; DELIZOICOV, 2015). As ações e atividades propostas no Plano de Ensino do Quadro 2, mesmo que preliminares, podem ser rediscutidas e ampliadas, na busca por parcerias com o poder público, na promoção e desenvolvimento de políticas públicas, agenda de pesquisa e agenda educacional (AULER, N.; AULER, 2015). Assim, sinaliza-se um novo caminho para estruturação curricular, que não só elenque conteúdos e conceitos científicos, mas que oriente ações que visem à transformação social, tal como sugerido por Auler e Delizoicov (2015) e Roso e Auler (2016).

No que concerne às perspectivas teórico-metodológicas deste estudo, o Ciclo Temático apresenta-se como um elemento organizador de foco metodológico, estruturado na problematização e sistematização das causas, consequências e alternativas para a superação das contradições sociais (FONSECA, 2017). Por isso, os parâmetros teóricos que orientaram essa discussão, pautaram-se na Rede Temática de Silva (2004) que, em síntese, reproduz o processo de Investigação Temática revelando a visão da comunidade e a visão dos educadores sob as problemáticas locais, articulando-as a aspectos da organização micro e macro social (SILVA, 2004).

Auler e Delizoicov (2015) defendem a necessidade da reinvenção da Redução Temática de forma a orientar processos de produção em Ciência-Tecnologia, em sintonia com as concepções de Freire e do PLACTS, considerando as demandas locais no desenvolvimento 
de agendas de pesquisa, políticas públicas e currículos escolares. Fato que pela presente discussão, apresenta-se como possível. Neste ponto, caracteriza-se a Redução Temática como consequência das três etapas que a antecedem, as quais sejam: 1) Levantamento Preliminar; 2) Análise e escolha das codificações; 3) Diálogos Descodificadores. Ao promover a reinvenção da Redução Temática como um encaminhamento futuro, salienta-se que esta seja considerada desde o Levantamento Preliminar, isto é, na compreensão, sistematização e problematização das intencionalidades e valores que direcionam o início da Investigação Temática.

\section{Referências}

AULER, D. Interações entre ciência-tecnologia-sociedade no contexto da formação de professores de ciências. Tese de doutorado em Educação - Universidade Federal de Santa Catarina, Florianópolis, 2002.

AULER, D. Novos Caminhos para a Educação CTS: Ampliando a Participação. In: SIMPÓSIO NACIONAL DE TECNOLOGIA E SOCIEDADE, 4, Curitiba, 2011.

AULER, N. M. F; AULER, D. Conhecer e executar currículos: ampliando o processo formativo de educadores(as). In: AULER, N.M.F.; AULER. D. (orgs.). Concepção e execução do currículo no processo formativo de Licenciandos do PIBID. Curitiba: CRV, 2015. p. 13-40.

AULER, D.; DELIZOICOV, D. Investigação de temas CTS no contexto do pensamento latino-americano. Linhas Críticas, v.21, n.45, p. 275-296, 2015.

CENTA, F. G.; MUENCHEN, C. O Despertar para uma Cultura de Participação no Trabalho com um Tema Gerador. Alexandria - Revista de Educação em Ciência e Tecnologia, v.9, n.1, p.263-291, 2016.

DAGNINO, R. A Relação Universidade-Empresa no Brasil e o "Argumento da Hélice Tripla". Revista Brasileira de Inovação, v. 2, n. 2, p. 267-307, 2003.

DELIZOICOV, D. Concepção Problematizadora do Ensino de Ciências na Educação Formal. Dissertação de mestrado em Educação, Pontifícia Universidade Católica, São Paulo, 1982.

DELIZOICOV, D. Conhecimento, tensões e transições. 1991. 219f. Tese (Doutorado) Faculdade de Educação, USP, São Paulo, 1991.

DELIZOICOV, D.; AULER, D. Ciência, Tecnologia e Formação Social do Espaço: questões sobre a não-neutralidade. Alexandria - Revista de Educação em Ciência e Tecnologia, v.4, n.2, p. 247-273, 2011.

DELIZOICOV, D.; ANGOTTI, J. A. P.; PERNAMBUCO, M. M. C. A. Ensino de Ciências: Fundamentos e Métodos. São Paulo: Cortez, 2011. 
FONSECA, K. N. Investigação Temática e a Formação Social do Espaço: construção de uma proposta com professores dos anos iniciais. Dissertação de mestrado em Educação em Ciências, Universidade Estadual de Santa Cruz, Ilhéus, 2017.

FREIRE, P. Pedagogia do oprimido. 17 ed. Rio de Janeiro: Paz e Terra, 1987.

FREIRE, P. Conscientização - teoria e prática da libertação: uma introdução ao pensamento de Paulo Freire. São Paulo: Cortez \& Moraes, 1979.

FREIRE, P. Extensão ou comunicação? 7 ed. Rio de Janeiro: Paz e Terra, 1983.

FURLAN, A. B. S.; RICCI, E. C.; GOMES, C. G. S.; SILVA, A. F. G. Tema Gerador no Ensino de Ciências: uma experiência curricular freireana vivenciada no PIBID. In: SOUSA, M. C.; MARQUES, C. P. (Orgs.) Formação inicial de professores: parceria universidadeescola na formação de licenciandos. Curitiba: Apris, 2013. p. 73-94.

HUNSCHE, S.; DELIZOICOV, D. A Abordagem Temática na Perspectiva da Articulação Freire-CTS: Um Olhar para a Instauração e Disseminação da Proposta. In: ENCONTRO NACIONAL DE PESQUISA EM EDUCAÇÃO EM CIÊNCIAS (ENPEC), 8, Campinas, 2011.

HOUAISS, A.; VILLAR, M. S. Minidicionário Houaiss da língua portuguesa. Organizado pelo Instituto Antônio Houaiss de Lexicografia e Banco de Dados da Língua Portuguesa S/C Ltda . $2^{\text {a }}$ Ed. rev.e ampl. Rio de Janeiro: Objetiva, 2004.

MAGALHÃES, R. Abordagem Temática Freireana na formação de professores de ciências sob a ótica da Teoria da Atividade. Dissertação de mestrado em Educação Científica e Formação de Professores - Universidade Estadual do Sudoeste da Bahia, Jequié, 2015.

MAGALHÃES, R. S.; SOLINO, A. P.; SOUSA, P. S.; FONSECA, K. N.; NOVAIS, E. S. P.; GEHLEN, S. T. Situações-limite na Formação de Professores de ciências na perspectiva freireana: da percepção da realidade à dimensão pedagógica. Investigações em Ensino de Ciências, v.21, n.3, p. 127-151, 2016.

MILLI, J. C. L. Análise textual discursiva: um caminho na investigação do Tema Gerador para o ensino de ciências/física. Monografia de Licenciatura em Física - Universidade Estadual de Santa Cruz, Ilhéus, 2016.

MILLI, J. C. L.; SOLINO, A. P.; GEHLEN, S.T. Análise Textual Discursiva na Investigação do Tema Gerador: por onde e como começar? Investigações em Ensino de Ciências, v.23, p. 200-229, 2018.

MORAES, R.; GALIAZZI, M. C. Análise Textual Discursiva. 2. ed. Ijuí: UNIJUÍ, 2011.

NERES, C. A. O processo de Investigação Temática no contexto da formação de professores de Ciências: um olhar a partir de Fleck. Dissertação de mestrado em Educação em Ciências Universidade Estadual de Santa Cruz, Ilhéus, 2016.

NOVAIS, E. S. P. Contribuições da Abordagem Temática Freireana para o Ensino de Ciências de uma Escola do Campo de Iguaí/BA. Dissertação de mestrado em Educação em Ciências - Universidade Estadual de Santa Cruz, Ilhéus, 2015.

REHDER, S. O. (Ed.). Guia Costa do Cacau. Porto Seguro, BA: Porto card, 2008. 
ROSA, S. E.; AULER, D. A não neutralidade da ciência-tecnologia: Problematizando silenciamentos em práticas educativas CTS. Alexandria - Revista de Educação em Ciência e Tecnologias, v. 9, p. 203-231, 2016.

ROSO, C. C. A participação na construção do currículo: práticas educativas vinculadas ao movimento CTS. Dissertação de mestrado em Educação - Universidade Federal de Santa Maria, Santa Maria, 2014.

ROSO, C. C.; SANTOS, R. A.; ROSA, S. E.; AULER, A. Currículo temático fundamentado em Freire-CTS: engajamento de professores de física em formação inicial. Revista Ensaio: Pesquisa em Educação em Ciências, v.17, n. 2, p. 372-389, 2015.

ROSO, C. C.; AULER, D. A Participação na Construção do Currículo: Práticas Educativas Vinculadas ao Movimento CTS. Ciências \& Educação, v. 22, n. 2, p. 371-389, 2016. SANTOS, R. A. Busca de uma participação social para além da avaliação de impactos da Ciência-Tecnologia na Sociedade: sinalizações de práticas educativas CTS. Tese de doutorado em Educação - Universidade Federal de Santa Maria, Santa Maria, 2016.

SÃO PAULO. Secretaria Municipal de Educação. Estudo preliminar da realidade local: resgatando o cotidiano. In: Cadernos de Formação. Série: Ação pedagógica na escola pela via da interdisciplinaridade. São Paulo: DOT/SME-SP, 1990.

SILVA, A. F. G. A construção do currículo na perspectiva popular crítica: das falas significativas às práticas contextualizadas. Tese de doutorado em Educação e Currículo Pontifícia Universidade Católica, SP, 2004.

SOLINO, A.P. Abordagem Temática Freireana e o Ensino de Ciências por Investigação: Contribuições para o ensino de Ciências/Física nos anos iniciais. Dissertação de mestrado em Educação Científica e Formação de Professor - Universidade Estadual do Sudoeste da Bahia, Jequié, 2013.

SOUSA, P. S.; BASTOS, A. P. S.; FIGUEIREDO, P. S.; GEHLEN, S. T. Investigação Temática no Contexto do Ensino de Ciências: Relações entre a Abordagem Temática Freireana e a Práxis Curricular via Tema Gerador. Alexandria - Revista de Educação em Ciência e Tecnologia, v. 7, n. 2, p. 155-177, 2014.

STRIEDER, R. B. Abordagens CTS na educação científica no Brasil: Sentidos e perspectivas. Tese de doutorado em Ensino de Ciências - Universidade de São Paulo, São Paulo, 2012.

STRIEDER, R. B.; WATANABE, G.; SILVA, K. M. A.; WATANABE, G. Educação CTS e Educação Ambiental: Ações na Formação de Professores. Alexandria - Revista de Educação em Ciência e Tecnologia, v.9, n.1, p. 57-81, 2016.

TORRES, J. R.; GEHLEN, S. T.; MUENCHEN, C.; GONÇALVES, F.P; LINDEMANN, R. H. GONÇALVES, F.J.F. Ressignificação curricular: contribuições da Investigação Temática e da Análise Textual Discursiva. Revista Brasileira de Pesquisa em Ensino de Ciências. v. 8, n.2, p. 1- 13, 2008.

\section{Agradecimentos}

Agradecemos ao apoio das agências de fomento CNPq, Capes, FAPESB e a Secretaria Municipal de Educação de Santa Luzia/BA. 


\section{SOBRE OS AUTORES}

JÚLIO CÉSAR LEMOS MILLI. Possui Licenciatura Plena em Física pela Universidade Estadual de Santa Cruz - UESC (2017). Mestrando no Programa de Pós-Graduação em Educação em Ciências (PPGEC/UESC), bolsista - Capes. Faz parte do Grupo de Estudos e Pesquisa sobre Abordagem Temática no Ensino de Ciências - GEATEC. Tem experiência na pesquisa em Educação, com ênfase no estudo e desenvolvimento de articulações teóricometodológicas entre pressupostos do educador Paulo Freire e a Análise Textual Discursiva, atuando no contexto da formação de professores do sul da Bahia, Costa do Cacau. Tem interesse pelos temas: Abordagem Temática Freireana, Análise Textual Discursiva e Educação CTS.

ELIANE DOS SANTOS ALMEIDA. Licenciada em Química pela Universidade Federal do Recôncavo da Bahia (2015). Mestre em Educação em Ciências pela Universidade Estadual de Santa Cruz - UESC (2018). Tem interesse pela área de Ensino de Ciências, com ênfase em discussões relacionadas a reconfigurações curriculares, atuando nos seguintes temas: Abordagem Temática Freireana e Educação CTS.

SIMONI TORMÖHLEN GEHLEN. Graduada em Física Licenciatura Plena pela Universidade Federal de Santa Maria (2002), mestrado em Educação nas Ciências pela Universidade Regional do Noroeste do Estado do Rio Grande do Sul - UNIJUÍ (2006) e doutorado em Educação Científica e Tecnológica pela Universidade Federal de Santa Catarina - UFSC (2009). Atualmente é professora do curso de Licenciatura em Física da Universidade Estadual de Santa Cruz - UESC e do Programa de Pós Graduação em Educação em Ciências desta universidade. Tem experiência na área de Educação, com ênfase em Ensino de Ciências/Física, atuando principalmente nos seguintes temas: Práticas Freireanas no Ensino de Ciências, aproximações entre as ideias de Lev S. Vygotsky e Paulo Freire e Abordagem Temática Freireana.

Recebido: 20 de janeiro de 2017.

Revisado: 16 de agosto de 2017.

Aceito: 26 de outubro de 2017. 